\title{
Effect of dietary inulin and oligosaccharides as prebiotics for weaning turbot, Psetta maxima (Linnaeus, C. 1758)
}

\author{
A. S. Mahious ${ }^{1^{*}}$, F. J. Gatesoupe ${ }^{2}$, M. Hervi ${ }^{2}$, R. Metailler ${ }^{2}$ and F. Ollevier ${ }^{1}$ \\ ${ }^{1}$ Laboratory of Aquatic Ecology, Katholieke Universiteit Leuven, De Bériotstraat 32, 3000 Leuven, Belgium \\ ${ }^{2}$ Fish Nutrition Laboratory, Unité Mixte Inra-Ifremer, Centre de Brest, 29280 Plouzané, France \\ *: Corresponding author: Phone: +32-16-323948 Fax: +32-16-324575 \\ Email: amal.mahious@bio.kuleuven.ac.be
}

\begin{abstract}
Preliminary experiments were undertaken to investigate the effect of dietary inulin (Raftiline ST), oligofructose (Raftilose P95) and lactosucrose on the growth and intestinal bacteria of the marine carnivorous turbot, Psetta maxima. Turbot larvae were weaned on compound diets containing $2 \%$ Rafiline ST, 2\% Raftilose P95 or 2\% lactosucrose; $2 \%$ cellulose was the carbon source in the control group. The final mean weight of the group weaned with Raftilose P95 was significantly higher than those observed with the other diets. The bacterial load was highly variable in weaning turbot, especially with respect to the putative Vibrio spp. growing on TCBS agar which, in general, seemed to be dominant. Of the total load of bacterial isolates from turbot weaned on oligofructose, $14 \%$ consisted of a strain of Bacillus spp. This strain could use Raftilose P95 as a single source of carbon, and it might play a role in the beneficial effect of oligofructose on turbot growth, since Bacillus spp. have been documented as probiotics in fish.
\end{abstract}

Keywords: Fish nutrition - Fructo-oligosaccharides - Intestinal flora - Prebiotics - Turbot 


\section{Introduction}

The main challenges in European turbot production is to improve feed formulation in order to optimize fish growth and fish resistance through the development of health promoting diets.

Prebiotics and probiotics were originally proposed for human health-enhancing food (Gibson and Roberfroid, 1995). Probiotics include viable lactic acid bacteria and other Bacilli that are able to survive in the intestine. Prebiotics include carbohydrates that are not digested in the upper part of the gastrointestinal tract, but selectively fermented by bacteria in the colon. This selective fermentation affects the composition of the intestinal microflora by stimulating Bifidobacteria and Lactobacilli, both in humans and in animals, where these bacteria have health promoting properties (Gibson and Roberfroid, 1995; Van Loo et al., 1999; Flamm et al., 2001). The importance of the intestinal microbiota in fish has been better understood during the last decade, while lactic acid bacteria were detected in fish microbiota (Ringø et al., 1995). To induce an artificial dominance, lactic acid bacteria were administrated to fish fry with encouraging results (Ringø and Gatesoupe, 1998). In fish larviculture, probiotics are inoculated in the rearing water, and they may be incorporated in the food chain by allowing the live food organisms, Artemia and rotifers, to graze on the probiotic strain. There were also some attempts to introduce probiotics into compound diets for fish (Gatesoupe, 1999; Ringø and Birkbeck, 1999; Verschuere at al., 2000). However, the probiotics strains can keep dominant in the gastrointestinal tract only during the dietary treatment. It is unlikely that such an exogenous addition of a single probiotic will result in long-term colonisation of the gut, especially when the strains used do not belong to the normal dominant intestinal flora. In those cases it is necessary to develop innovative strategies in order to establish stable and healthy gastrointestinal microbiota in fish.

The stimulation of specific indigenous microflora by supplementing fish feed with indigestible carbohydrates that act as prebiotic, could be an interesting approach to increase the proportion of health-promoting bacteria in the gut. There are few studies dealing with the influence of prebiotics on the intestinal microflora of fish. Lactosucrose was used as substrate for the intestinal microflora, and it increased the thickness of intestinal tunica muscularis in red sea bream, Pagrus major (Kihara et al., 1995). However, lactosucrose was poorly used by microbiota in carp (Kihara and Sakata, 2001a) and trout (Kihara and Sakata, 2001b). Recently, Olsen et al. (2001) observed a damaging effect of inulin on enterocytes of Arctic charr, Salvelinus alpinus L., but the concentration used was quite high (15\% of the diet).

The present experiments were designed to study the effects of dietary inulin, oligofructose and lactosucrose, on the microbial ecology of the digestive tract, and on the growth of turbot at the weaning stage.

\section{Material and methods}

\section{Animals}

Turbot larvae (Psetta maxima) used in this study were obtained from France Turbot (Noirmoutier, France). The larval rearing was conducted at IFREMER, Brest, France, according to the method described by Gatesoupe (1990).

The newly hatched larvae were transferred to 150 litres conical fiber glass tanks (stocking density: 20 larvae $\mathrm{l}^{-1}$ ). These tanks were supplied with running seawater passed through a sand filter, a heat exchanger, then a degassing column. The temperature was maintained at $18^{\circ} \mathrm{C}$ at a salinity of $35 \%$. The larvae were submitted to continuous illumination. 
From 3 to 7 days post hatching (dph), turbot larvae were fed with enriched Brachionus rotundiformis with daily amounts increasing from 20 to 150 rotifers per larva. The rotifers were fed daily with backer's yeast $\left(60 \mathrm{mg} \mathrm{l}^{-1}\right.$, on a dry matter basis), a self-emulsifying concentrate of essential fatty acids DHA Selco (INVE, Belgium, $18 \mathrm{mg} \mathrm{l}^{-1}$ ) and T-Isochrysis affinis galbana (ca. $10^{5}$ cells ml $^{-1}$ ). The rotifers were then transferred to clean seawater, enriched with DHA Selco (18 $\left.\mathrm{mg} \mathrm{l}^{-1}\right)$ and distributed continuously to the larvae with a peristaltic pump. Artemia nauplii ( $1 \mathrm{dph})$ were enriched with DHA Selco (150 $\left.\mathrm{mg} \mathrm{l}^{-1}\right)$ and dried brewer's yeast $\left(50 \mathrm{mg} \mathrm{l}^{-1}\right)$. Then, they were distributed into the larval rearing tanks from $8 \mathrm{dph}$ to $29 \mathrm{dph}$.

\section{Prebiotics}

Raftiline ST and Raftilose P95 are powdered food ingredients that contain mainly polydisperse $\beta(2 \rightarrow 1)$ linked fructans. Raftiline ST is a standard form of chicory inulin. Raftilose P95 contains mainly oligofructose produced by partial enzymatic hydrolysis of chicory inulin. The degree of polymerisation of the fructans ranged from 2 to 60 for Raftiline, and from 2 to 8 for Raftilose. The minimum amount of fructans guaranteed by the manufacturer was 90 and 93\% for Raftline ST and Raftilose P95, respectively. The other components were mainly glucose, fructose, and sucrose. These products were supplied by Raffinerie Tirlemontoise (Tienen, Belgium).

Lactosucrose $\left(4^{\mathrm{G}}-\beta\right.$-D-galactosylsucrose) is a trisaccharide synthesized from lactose and sucrose by transfructosylation of $\beta$-fructofranosidase. Lactosucrose LS-55P, obtained from Ensuiko Sugar Refining Co. (Yokohama, Japan), is a powder containing more than $55 \%$ lactosucrose, less than $25 \%$ lactose, and less than $10 \%$ sucrose.

\section{Diet Preparation}

Experimental diets were formulated to contain approximately $62 \%$ protein and $12 \%$ fat, in order to test the influence of oligosaccharides and inulin during the weaning of turbot (Table 1). A control diet (C) included $2 \%$ cellulose powder. In the test diets, cellulose (Arbocell B00, J. Rettenmaier \& Söhne, Germany) was substituted by 2\% Raftilin ST (diet S), 2\% Raftilose P95 (diet P) or 2\% lactosucrose (diet L). Extruded pellets were sieved to obtain particles with graded diameters (200-400 $\mu \mathrm{m}$; 400-600 $\mu \mathrm{m}$ and 600-1000 $\mu \mathrm{m}$ ), which were successively used according to fish size during the weaning experiment.

\section{Analytical method}

The diets were analysed with the following procedures: dry matter by drying at $105^{\circ} \mathrm{C}$ for $24 \mathrm{~h}$, ash by combustion at $550^{\circ} \mathrm{C}$ for $12 \mathrm{~h}$, crude protein by Dumas method, fat by dichloromethane extraction (Soxhlet), and energy in an oxygen bomb calorimeter. The proximate composition of the diets is given in Table 1.

\section{Experimental design}

At 29 dph, turbot larvae, previously fed on standard live food organisms (as explained above), were transferred to the experimental facilities. Their initial mean weight was $45.5 \pm 1.9 \mathrm{mg}$. They were distributed randomly in 12 subsquare tanks (440 fish per tank). The tanks contained $50 \mathrm{l}$ seawater and were subjected to 18 light/6 dark photoperiod. The temperature was maintained at $18^{\circ} \mathrm{C}$. The larvae were weaned for 10 days by decreasing progressively the amount of Artemia, while increasing the amount of the experimental compound diets (Table 1). 
The larvae were fed continuously in excess the diets during one month, at the daily rate of $20-30 \%$ of the biomass. Each diet was tested in triplicates. Fish were weighed at the start and at the end of the experiment. At 29 and 55 dph larvae were sampled for bacterial analysis as described below.

\section{Sampling and bacterial examination}

Two larvae were sampled in each tank at 29 and $56 \mathrm{dph}$. The fish were euthanized with an overdose of 2-phenoxyethanol, and the corporal surface was disinfected in a solution of $0.1 \%$ benzalkolium chloride (Sigma, USA). Larvae were then dissected under sterile conditions and the gut was removed, weighed and homogenized. After homogenisation, appropriate dilutions of the three samples for each treatment were spread on Petrifilm (Aerobic Count Plates, 3M Microbiology products, USA) and TCBS agar (thiosulfate-citrate-bile-salt agar, AES Laboratoire, France, dissolved in half-strength seawater). MRS and Sabouraud Agars were also used to detect lactic acid bacteria and yeast, respectively (Gatesoupe, 2002). All the plates were incubated at $20^{\circ} \mathrm{C}$ and inspected up to 5 days. Eight colonies were randomly isolated from each individual Petrifilm for phenotypic characterisation.

These selected isolates were cultivated on plate count agar (PCA, AES laboratoire, enriched with $18 \mathrm{~g} \mathrm{l}^{-1} \mathrm{NaCl}$, $\mathrm{pH}$ adjusted to 7.8) and stored under liquid nitrogen before further genotypic characterisation.

\section{Phenotypic characterisation}

The Phenotypes of the isolates were characterised with API 20 E strips according to the manufacturer's instructions (BioMérieux, France). The API 20 E profiles were compared and classified with the Wagner parsimony method, by using Mix of Phylip (Felsenstein, 1996). The isolates representative of the different phenotypic profiles were cultured again for DNA extraction.

\section{Genotypic characterisation}

DNA was extracted and the fragments corresponding to 16S rDNA were amplified by PCR. The isolates were clustered according to their genotypic similarity, characterised by Amplified Ribosomal Dna-Restriction Analysis (ARDRA) of the PCR products by using Hae III and Cfo I (Gatesoupe, 2002). One isolate per each dominant cluster was selected for sequencing the 16S rDNA gene (partial sequences of $702-753 \mathrm{bp}$ from primer SA-dir 5'-agagtttgatcatggctcag-3'). The phylogenic position of the cluster was then searched with BLAST (NCBI).

\section{Ability of bacterial isolates to use inulin and oligofructose}

Selected isolates were tested for Hugh and Leifson's fermentation test applied to Raftiline ST and to Raftilose P95 under anaerobic conditions (Hugh and Leifson, 1953), and for their ability to use these products as single carbon source in Baumann medium (Baumann et al., 1971). The test tubes were incubated at $20^{\circ} \mathrm{C}$, and checked up to 5 days.

\section{Statistical Analysis}

To test differences between dietary treatments, all data were subjected to one-way analysis of variance (ANOVA, SigmaStat 2.0), after checking normality and homogeneity of variance. The bacterial counts were log-transformed. When the parametric analysis was not applicable, Kruskall-Wallis ANOVA on ranks was tested. When significant differences were observed, the effects of the individual treatments 
were further compared with Tukey's or Dunn's method, after parametric or nonparametric ANOVA, respectively.

\section{Results}

\section{Growth and survival}

Feeds were well accepted during the experimental period. High weaning survival rates were obtained, without any significant difference (82-89 \%, Table 2). The growth rate was significantly improved with diet $\mathrm{P}$ that contained oligofructose (final mean weight of 0.50 vs. 0.41-0.43 g).

\section{Microbiota}

The bacterial counts were highly variable, and it was not possible to observe any significant difference between the amounts of bacteria, the mean of which was generally ca. $10^{3} \mathrm{CFU} \mathrm{g}^{-1}$ (Table 3). Before weaning at $29 \mathrm{dph}$, the intestinal microbiota was still dominated by Vibrio spp. which represented $96 \%$ of the isolates. After weaning at $55 \mathrm{dph}$, the dominance of Vibrio spp. was again observed in the control group, and in turbot fed with inulin. Two strains were dominant, Vibrio L2C55, closely related to V. ordalii 6.30 (Montes et al., 2003), and Vibrio sp. S12411, closely related to Vibrio sp. Csur-1 (Radjasa et al. 2001). Both strains were also observed in turbot weaned with oligofructose, but their dominance was less marked. Bacterial diversity was high in this latter group, with the emergence of Bacillus sp. L171P95, close to B. subtilis KL-077 and KL-073 (Venkateswaran et al., 2003). Microbiota could not be characterised in the group weaned with lactosucrose, because most of the isolates from Petrifilm did not grow on PCA plates. However, the high counts on TCBS plates suggested the dominance of Vibrio spp.

No colony was detected on MRS and Sabouraud agars along the experiment.

\section{Ability of bacterial isolates to use inulin and oligofructose}

Strains corresponding to the dominant Vibrio spp., and to Bacillus sp. were tested for their acid production, and for their use of Raftilose P95 and Raftilin ST as single carbon source. The growth of Bacillus sp. with Raftilose P95 as carbon source was faster than that obtained with glucose (Table 4). It is noteworthy that these strains did not produce organic acids, and that they did not grow with Raftilin ST, indicating that the nutritive value of Raftilose P95 was due to oligofructose, rather than due to the small proportion of mono- and disaccharadides contained in the commercial products.

\section{Discussion}

Raftilose P95 had a positive effect on the growth of weaning turbot. Further study is needed to interpret this effect, but the increased diversity in gut microbiota, and the specific emergence of Bacillus sp. may have played a role in this effect. Bacillus sp. have been seldom isolated from turbot (Austin, 1982, 1983). This genus has been evaluated as source of probiotics in aquaculture systems, by trying either to improve water quality or to reduce the incidence of pathogens in farmed species (Irianto and Austin, 2002). Autochthonous isolates have been used as biocontrol agents to reduce vibriosis in fish (Kennedy et al., 1998; Sugita et al., 1998), and in shrimp (Moriarty, 1998; Rengipat et al., 1998, 2000; Vaseeharan and Ramasamy, 2003). Commercial probiotic preparations containing Bacillus spp. have been also tested in fish (Gatesoupe, 1989, 1993; Queiroz and Boyd, 1998; Raida et al., 2003). In our study, the Bacillus strains were isolated only from turbot fed with Raftilose P95, while the proportion of Vibrio spp. was lower than in the other groups. The isolates of Bacillus 
sp. were able to use Raftilose P95 as single carbon source at a faster rate than Vibrio spp. These isolates inhibited also the growth of Vibrio anguillarum strains isolated from turbot (data not shown). Their potential as probiotics should be further investigated.

The high variability of the bacterial counts in the weaning experiment may be an indication that the prebiotic treatments were not sufficient alone to regulate microbiota. The combination of the probiotic and prebiotic treatments may be particularly important for fish where the gastrointestinal microbiota are variable (Ringø and Birkbeck, 1999), and much more dependent on the environment than those of terrestrial species. The strain of Bacillus sp. isolated in the present experiment could be particularly interesting in this context.

The treatment with lactosucrose did not significantly improved the growth of turbot. However, it is not possible to draw any conclusion about the interest of this compound as prebiotic for turbot. The relatively high amounts of lactose and sucrose contained in the commercial product might have affected microbiota, which seemed different from those of the other groups, though it was not efficiently characterised.

\section{Conclusion and perspective}

This preliminary study should encourage to further investigate the potential of prebiotics in fish compound diets. It should be necessary to improve the methods to survey the effect of prebiotics on microbiota, while considering also their possible effects on uncultivable and anaerobic bacteria. Preferably combined with probiotics, some prebiotics like oligofructose could be useful for the establishment of a stable and healthy gastrointestinal flora, especially in intensive larval culture where high mortalities are frequently encountered.

\section{Acknowledgements}

This work was carried out in the frame of ASEFAF, and supported by the ARI Programme "improving human potential for Research" from the European Union through contract HPRI-CT-2001-00146. ORAFTI (Sucreries Tirlemontoises, Belgium) have granted a scholarship to the first author, and they have freely furnished the prebiotics. The technical assistance of Jacques Moriceau and Hervé Le Delliou was highly appreciated. Thanks are also due to Dr. Nico Vromant for reading and correcting this manuscript.

\section{References}

Austin B. 1982. Taxonomy of bacteria isolated from a coastal, marine fish-rearing unit. J. Appl. Bacteriol. 53: 253-268.

Austin B. 1983. Bacterial microflora associated with a coastal, marine fish-rearing unit. J. Mar. Biol. Assoc. U.K. 63: 585-592.

Baumann P., Baumann L. and Mandel M. 1971. Taxonomy of marine bacteria: the genus Beneckea. Journal of Bacteriology 107: 268-294.

Felsenstein J. 1996. Inferring phylogenies from protein sequences by parsimony, distance, and likelihood methods. In: Doolittle R.F. (ed.), Computer Methods for Macromolecular Sequence Analysis. Methods in Enzymology, vol. 266. Academic Press, Orlando, FL, pp. 418-427. 
Flamm G., Glinsmann W., Kritchevsky D., Prosky L. and Roberfroid M. 2001. Inulin and oligofructose as dietary fiber: a review of the evidence. Critical Reviews of Food Science and Nutrition 4: 353-362.

Fournier V., Gouillou-coustans M.F., Métailler R., Vachot C., Ghedes M.J., Tulli F., Oliva-Teles A., Tibaldi E. and Kaushik S.J., 2002. Protein requirements for maintenance and nitrogen gain in four teleosts. Br. J. Nutr. 87: 459-467.

Gatesoupe F.J. 1989. Further advances in the nutritional and antibacterial treatments of rotifers as food for turbot larvae, Scophthalmus maximus L. In: De Pauw N., Jaspers E., Ackefors H. and Wilkins N. (eds.), Aquaculture - A Biotechnology in Progress. Eur. Aquacult. Soc., pp. 721-730.

Gatesoupe F.J. 1990. The continuous feeding of turbot larvae, Scophthalmus maximus, and control of the bacterial environment of rotifers. Aquaculture 89: 139-148.

Gatesoupe F.J. 1993. Bacillus sp. spores as food additive for the rotifer Brachionus plicatilis: Improvement of their bacterial environment and their dietary value for larval turbot, Scophthalmus maximus L. In: Kaushik S.J. and Luquet P. (eds.) 4th Int. Symp. Fish Nutrition and Feeding, Biarritz (France), 24-27 June 1991, Fish Nutrition in Practice, Institut National de la Recherche Agronomique, Paris (France), Colloq. INRA, no. 61, pp. 561-568.

Gatesoupe F.J. 1999 The use of probiotics in aquaculture: Review. Aquaculture 180: 147165.

Gatesoupe F.J. 2002. Probiotic and formaldehyde treatments of Artemia nauplii as food for larval pollack, Pollachius pollachius. Aquaculture 212: 347-360.

Gibson G.R. and Roberfroid M.B. 1995. Dietary modulation of the human colonic microbiota: introducing the concept of prebiotics. J. Nutr. 125: 1401-1412.

Hugh R and Leifson E. 1953. The taxonomic significance of fermentative versus oxidative metabolism of carbohydrates by various Gram-negative bacteria. Journal of Bacteriology 66: 24-26.

Irianto A. and Austin B. 2002. Probitotics in aquaculture. Journal of Fish Diseases 25: 633-642.

Kennedy S.B., Tucker J.W., Neidic C.L., Vermeer G.K., Cooper V.R., Jarrell J.L. and Sennet D.G. 1998. Bacterial management strategies for stock enhancement of warmwater marine fish: a case study with common snook (Centropomus undecimalis). Bulletin of Marine Science 62: 573-588.

Kihara M., Ohba K. and Sakata T. 1995. Trophic effect of dietary lactosucrose on intestinal tunica muscularis and utilization of this sugar by gut microbes in red seabream, Pagrus major, a marine carnivorous teleost, under artificial rearing. Comp. Biochem. Physiol. 112: 629-634.

Kihara M. and Sakata T. 2001a. Effects of rearing temperature and dietary on the production of gases and organic acids by gut microbes of an omnivorous Teleost, carp, Cyprinus carpio, in micro-scale batch cultures. Suisanzoshoku 49: 329-338.

Kihara M. and Sakata T. 2001b. Influence of incubation temperature and various saccharides on the production of organic acids and gases by gut microbes of rainbow 
trout, Onchorhynchus mykiss in a micro-scale batch culture. Journal of Comprehensive Physiology B 171: 441-447.

Montes M., Farto R., Pérez M.J., Nieto T.P., Larsen J.L. and Christensen H. 2003. Characterisation of Vibrio strains isolated from turbot (Scophthalmus maximus) cultured by phenotypic analysis, ribotyping and 16S rRNA gene sequence comparison. Journal of Applied Microbiology 95: 693-703.

Moriarty D.J. 1998. Control of luminous Vibrio species in penaeid aquaculture ponds. Aquaculture 164: 351-358

Olsen R.E., Myklebust R., Kryvi H., Mayhew T.M. and Ringø E. 2001. Damaging effect of dietary inulin on intestinal enterocytes in Arctic charr (Salvelinus alpinus L.). Aquaculture Research 32: 931-934.

Queiroz J.F.and Boyd C.E. 1998. Effect of bacterial inoculum in channel catfish ponds. Journal of the World Aquaculture Society 29: 67-73.

Radjasa O.K., Urakawa H., Kita-Tsukamoto K. and Ohwada K. 2001. Characterization of psychrotrophic bacteria in the surface and deep-sea waters from the northwestern Pacific Ocean based on 16S ribosomal DNA analysis. Mar. Biotechnol. 3: 454-462.

Raida M.K., Larsen J.L., Nielsen M.E. and Buchmann K. 2003. Enhanced resistance of rainbow trout, Oncorhynchus mykiss (Walbaum), against Yersinia ruckeri challenge following oral administration of Bacillus subtilis and B. licheniformis (BioPlus2B). J. Fish Dis. 26: 495-498.

Rengpipat S., Phianphank W., Piytitratitivorakul S. and Menasveta P. 1998. Effects of probiotic bacterium in black tiger shrimp Penaeus monodon survival and growth. Aquaculture 167: 301-313.

Rengpipat S., Rukpratanporn S., Piyatiratitivorakul S. and Menasaveta P., 2000. Immunity enhancement in black tiger shrimp (Penaeus monodon) by a probiont bacterium (Bacillus S11). Aquaculture 191: 271-288.

Ringø E. and Birkbeck T.H. 1999. Intestinal microflora of fish larvae and fry. Aquaculture Research 30: 73-93.

Ringø E. and Gatesoupe F.J. 1998. Lactic acid bacteria in fish: a review. Aquaculture 160: 177-203.

Ringø E., Strøm E.and Tabachek J.A. 1995. Intestinal microflora of salmonids: a review. Aquaculture Research 26: 773-789.

Sugita H., Hirose Y., Matsuo N. and Deguchi Y. 1998. Production of the antibacterial substance by Bacillus sp. strain NM 12, an intestinal bacterium of Japanese coastal fish. Aquaculture 165: 269-280.

Van Loo J., Cummings J., Delzenne N., Franck A., Hopkins M., MacFarlane G., Newton D., Quigely M., Roberfroid M., Van Vliet T. and Van den Heuvel E. 1999. Functional food properties of non-digestible oligosaccharide: a consensus report from the ENDO project (DGXII AIRII-CT94-1095). Brit. J. Nutr. 81: 121-132.

Vaseeharan B. and Ramasamy P. 2003. Control of pathogenic Vibrio spp. by Bacillus subtilis BT23, a possible probiotic treatment for black tiger shrimp, Penaeus monodon. Letters in Applied Microbiology 36: 83-87.

Venkateswaran K., Hattori N., La Duc M.T. and Kern R. 2003. ATP as a biomarker of viable microorganisms in clean-room facilities. J. Microbiol. Methods 52: 367-377. 
Verschuere L., Rombaut G., Sorgeloos P. and Verstraete W. 2000. Probiotic Bacteria as Biological Control Agents in Aquaculture. Microbiology and Molecular Biology Reviews 64: 655-671. 


\section{Table 1}

Composition of the diets

Ingredients (\%)

\begin{tabular}{|c|c|}
\hline Fish meal & 59.9 \\
\hline Fish concentrate protein & 14 \\
\hline Pre-cooked starch & 12 \\
\hline Cod liver oil & 4 \\
\hline Soybean lecithin & 2 \\
\hline Mineral mixture (INRA 736) & 2 \\
\hline Vitamin mixture (INRA CV762) & 2 \\
\hline Guar & 2 \\
\hline Inosin & 0.1 \\
\hline Cellulose or Prebiotic $^{\varepsilon}$ & 2 \\
\hline
\end{tabular}

\begin{tabular}{lllll}
\hline Proximate analyses (\%dry matter) & $\mathrm{C}$ & $\mathrm{S}$ & $\mathrm{P}$ & $\mathrm{L}$ \\
\hline Dry matter & 93.5 & 95.7 & 93.0 & 92.8 \\
Moisture (\% wet weight) & 6.5 & 4.3 & 7.0 & 7.2 \\
Protein & 61.7 & 62.2 & 62.0 & 61.5 \\
Fat & 11.5 & 11.8 & 11.8 & 12.5 \\
Ash & 10.4 & 10.3 & 10.3 & 10.3 \\
Energy & 22.6 & 22.6 & 22.9 & 22.8 \\
\hline
\end{tabular}

$\S$ Mineral and vitamin mixes detailed by Fournier et al. (2002)

${ }^{\text {E }}$ Cellulose powder, Raftilin ST, Raftilose P95 and lactosucrose were added in diets C, S, P and L, respectively 
Table 2

Effect of prebiotics on turbot growth at the weaning stage

\begin{tabular}{cccc}
\hline Treatment & $\begin{array}{c}\text { Final mean } \\
\text { weight }\end{array}$ (g) & SGR $^{\S}$ & $\begin{array}{c}\text { Survival rate } \\
(\%)\end{array}$ \\
\hline C & $0.41 \pm 0.02^{\mathrm{b}}$ & $8.4 \pm 0.4$ & $88.6 \pm 1.7$ \\
S & $0.41 \pm 0.02^{\mathrm{b}}$ & $8.4 \pm 0.2$ & $82.1 \pm 1.8$ \\
$\mathrm{P}$ & $0.50 \pm 0.02^{\mathrm{a}}$ & $9.2 \pm 0.2$ & $87.4 \pm 1.3$ \\
$\mathrm{~L}$ & $0.43 \pm 0.02^{\mathrm{b}}$ & $8.6 \pm 0.2$ & $85.7 \pm 0.9$ \\
\hline
\end{tabular}

${ }^{\S}$ Specific Growth Rate $=[(\mathrm{LnFW}-\mathrm{LnIW}) / \mathrm{t}] \times 100 ; \mathrm{FW}$ : final mean weight for each replicate; IW: initial mean weight ( $46 \pm 2 \mathrm{mg})$; $\mathrm{t}=$ time (26 days)

${ }^{£}$ Means \pm S.E. with different superscripts for significantly different means in Tukey's test; ${ }^{* *} P<0.01, \mathrm{n}$ $=90$

\# Survival rate (not significantly different, $\mathrm{n}=3$ ) 
Table 3

Effect of prebiotics on intestinal microbiota in weaning turbot

\begin{tabular}{|c|c|c|c|c|c|}
\hline \multirow[b]{2}{*}{ Group } & \multirow{2}{*}{$\begin{array}{l}29 \mathrm{dph} \\
\text { Initial }\end{array}$} & \multicolumn{4}{|c|}{$55 \mathrm{dph}$} \\
\hline & & $\mathrm{C}$ & $S$ & $\mathrm{P}$ & $\mathrm{L}$ \\
\hline $\begin{array}{l}\text { Petrifilm counts } \\
\left(\log C F U g^{-1}\right)\end{array}$ & $3.2 \pm 1.4$ & $3.6 \pm 0.3$ & $2.8 \pm 0.3$ & $3.0 \pm 0.4$ & $2.3 \pm 0.5$ \\
\hline $\begin{array}{l}\text { TCBS counts@ } \\
\left(\log \text { CFU g }{ }^{-1}\right)\end{array}$ & $3.1 \pm 1.4$ & $2.7 \pm 0.9$ & $3.8 \pm 0.9$ & $1.8 \pm 1.2$ & $3.7 \pm 1.3$ \\
\hline Vibrio sp. S12411 $(\%)$ & nd & 28 & 22 & 16 & 5 \\
\hline Vibrio sp. L2C55 (\%) & nd & 36 & 44 & 25 & 5 \\
\hline Bacillus sp. L171P95" (\%) & nd & nd & nd & 14 & nd \\
\hline Other bacteria (\%) & 100 & 36 & 34 & 45 & 90 \\
\hline
\end{tabular}

${ }^{\circledR}$ Bacterial counts: means \pm S.E., Kruskall-Wallis ANOVA on ranks not significant, $n=6$

The identification was based on alignment with nucleotide sequences currently available in NCBI database; ${ }^{\S}$ Accesion number of an homologous fragment: AF293974, position of the first and last nucleotides corresponding to the fragment in the referenced sequence: $43-605 ;{ }^{\complement}$ Accession number: AJ634477, sequence deposited for this study; ${ }^{\#}$ accession numbers of an homologous fragment: AY030331, position of the first and the last nucleotides corresponding to the fragments in the referenced sequence: 53-785.

nd: not detected 


\section{Table 4}

Carbohydrate utilization of selected strains isolated from turbot weaned with Raftilose P95

\begin{tabular}{|c|c|c|c|c|c|c|}
\hline \multirow[t]{2}{*}{ Strains } & \multicolumn{3}{|c|}{ Acid production (Hugh and Leifson) } & \multicolumn{3}{|c|}{ Utilization as single source of carbon } \\
\hline & Glucose & Raftilose P95 & Raftiline ST & Glucose & Raftilose P95 & Raftiline ST \\
\hline \multicolumn{7}{|l|}{ Vibrio sp. S12411 ${ }^{£}$} \\
\hline L144P95 & $(+)$ & + & $(+)$ & + & $(+)$ & - \\
\hline L145P95 & $(+)$ & + & - & + & - & - \\
\hline L173P95 & - & - & - & $\mathrm{nt}$ & nt & nt \\
\hline \multicolumn{7}{|l|}{ Vibrio sp. L2C55 } \\
\hline L183P95 & $(+)$ & + & $(+)$ & + & - & - \\
\hline L136P95 & $(+)$ & + & $(+)$ & + & $(+)$ & - \\
\hline L133P95 & $(+)$ & + & $(+)$ & + & - & - \\
\hline L134P95 & $(+)$ & + & $(+)$ & + & $(+)$ & - \\
\hline L131P95 & $(+)$ & + & $(+)$ & + & - & - \\
\hline Vibrio sp. L162P95@ & $(+)$ & + & $(+)$ & + & + & - \\
\hline \multicolumn{7}{|l|}{ Bacillus sp. } \\
\hline L161P95 & - & - & - & + & ++ & - \\
\hline L171P95 & - & - & - & + & ++ & - \\
\hline
\end{tabular}

The identification was based on alignment with nucleotide sequences currently available in NCBI database; ${ }^{£}$ see Table 3 ; ${ }^{\#}$ see Table 3 ; ${ }^{@}$ accession numbers of an homologous fragment: AJ437193, position of the first and the last nucleotides corresponding to the fragments in the referenced sequence: $37-755$.

nt: not tested; (+):weak or delayed reaction, +: positive reaction; ++: faster growth; -: negative reaction 